Phytochemical composition of ground paprika from the eastern Danube region

Fitokemijski sastav mljevene začinske paprike iz istočne Dunavske regije

Vinković, T., Gluščić, V., Mendaš, G., Vinković Vrček, I., Parađiković, N., Tkalec, M., Štolfa Čamagajevac, I.

Poljoprivreda/Agriculture

ISSN: $1848-8080$ (Online)

ISSN: 1330-7142 (Print)

http://dx.doi.org/10.18047/poljo.24.2.1

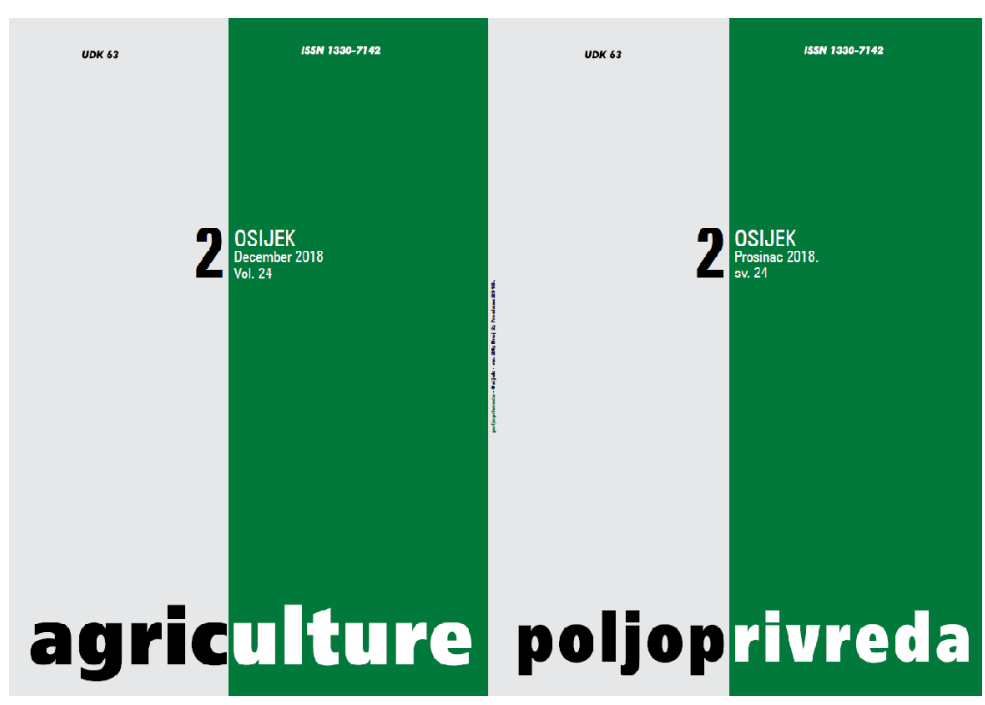

Fakultet agrobiotehničkih znanosti Osijek, Poljoprivredni institut Osijek

Faculty of Agrobiotechnical Sciences Osijek, Agricultural Institute Osijek 


\title{
PHYTOCHEMICAL COMPOSITION OF GROUND PAPRIKA FROM THE EASTERN DANUBE REGION
}

\author{
Vinković, T. ${ }^{(1)}$, Gluščić, V.(2), Mendaš, G. ${ }^{(2)}$, Vinković Vrček, I. ${ }^{(2)}$, Parađiković, N. ${ }^{(1)}$, Tkalec, M. ${ }^{(1)}$, \\ Štolfa Čamagajevac, $I .^{(3)}$
}

Original scientific paper

Izvorni znanstveni članak

\begin{abstract}
SUMMARY
This study aimed to evaluate the phytochemical composition of sweet and hot ground paprika originating from different production sites in the Eastern Danube Region, i.e. in Croatia, Serbia and Hungary. Obtained results showed that composition and level of metabolites as well as antioxidant activity in paprika samples varied greatly among different locations. For the first time, clear differences in the chemical composition of sweet and hot paprika obtained from two Hungarian wax pepper cultivars produced in three different states of the Eastern Danube region were determined. Averagely, paprika samples from Croatia had the highest carotenoid content but the lowest levels of phenols and flavonoids. The hot paprika samples from Croatia had the highest content of capsaicin and dihydrocapsaicin. Thus, the results of this investigation indicate that bioactive compounds in paprika can vary greatly depending on their geographical origin. However, this variation can also occur due to different production technology and processing methods. Further investigations and methods need to be employed to determine the factors responsible for variation of content of bioactive compounds in paprika.
\end{abstract}

Key-words: paprika, capsaicinoids, phenolics, carotenoids, antioxidative activity, Eastern Danube Region

\section{INTRODUCTION}

The word "paprika" originates from Hungary and denotes only the dried and ground fruits of the pepper plant Capsicum annuum L. that belongs to the Solanaceae family. In Europe, significant quantities of paprika are produced in Hungary, Serbia, Croatia, Spain and Macedonia where it is used in traditional cuisine. Paprika can be non-pungent or sweet and pungent or hot depending on the pepper cultivar grown. Pungency in paprika originates from the alkaloids called capsaicinoids, especially capsaicin and dihydrocapsaicin that are responsible for more than $90 \%$ of paprika's pungency (Cisneros-Pineda et al., 2007; Giuffrida et al., 2013).

Health benefits of capsaicinoids derive from their analgesic, anti-inflammatory and antioxidant activity, including anticarcinogenic properties inhibiting androgen-dependent growth of breast cancer, as well as colon, prostate and gastric adenocarcinoma (Djamgoz and Isbilen, 2006). Besides pungency, a very impor- tant property determining the quality of paprika is red coloration, determined by the level of ketocarotenoids capsanthin and capsorubin. Carotenoids are known to have a positive effect on human health such as cancer chemopreventive activity (Maoka et al., 2001). Also, other phytochemicals like phenolic compounds and flavonoids contribute to the overall quality of paprika. Flavonoids and phenolic compounds, known for their significant antioxidant and anticancer activity, are present in all pepper cultivars (Tonin et al., 2005; Lu et al., 2006). Thus, the combination of different phytochemi-

(1) Assoc. Prof. Tomislav Vinković, Prof. Dr. Nada Parađiković, Ph. D. Monika Tkalec - Josip Juraj Strossmayer University of Osijek, Faculty of Agrobiotechnical Sciences Osijek, Vladimira Preloga 1, 31000 Osijek, Croatia, (2) Valentina Gluščić, Mag. Chem., Ph. D. Gordana Mendaš Ph. D. Ivana Vinković Vrček - Institute for Medical Research and Occupational Health, Ksaverska cesta 2, 10000 Zagreb, Croatia, (3) Assist. Prof. Ivna Stolfa Čamagajevac (ivna.stolfa@biologija.unios.hr) - Josip Juraj Strossmayer University of Osijek, Department of Biology, Cara Hadrijana 8/A, 31000 Osijek, Croatia 
cals which determine the colour, taste and pungency of paprika is the reason for its worldwide popularity. The content of phytochemicals is generally influenced by several factors such as the genotype, environmental conditions, ripening stage and cultivation techniques (Giuffrida et al., 2013). Numerous studies have confirmed that drought, salinity, harvest date, storage conditions as well as production techniques and drying methods change the content of phytochemicals in pepper and/or ground paprika (Fox et al., 2005; Kalt, 2005; Phimchan and Techawongstien, 2012; Rahman and Inden, 2012; Reis et al., 2013; Zaki et al., 2013). To the best of our knowledge, there are no studies reporting the phytochemical composition of ground paprika produced in the Eastern Danube Region. This study aimed to compare the composition of flavonoids, carotenoids, phenols and capsaicinoids in sweet and hot ground paprika from several production sites in Croatia, Serbia and Hungary, which all belong to the Eastern Danube Region.

\section{MATERIAL AND METHODS}

\section{Plant materials}

For the determination of ground paprika's chemical composition, final products in form of ground paprika of two most commonly used hybrid pepper cultivars of Capsicum annuum L. were selected, cv. Kalocsai V2 and cv. Szegedi 80 . Kalocsai V2 is a hot variety with red pendulous fruits, while cv. Szegedi 80 is a sweet variety with red pendulous fruits. The commercial samples (final product - paprika that is a powdered spice of deep orange-red colour made from the dried and ground fruits of certain varieties of sweet or hot pepper) were collected and purchased from producers during season 2013/14 in Croatia, Serbia and Hungary. Both sweet and hot paprika samples were collected at each location. Locations in Croatia were Kopačevo $\left(45^{\circ} 36^{\prime} 9^{\prime \prime} \mathrm{N}\right.$,

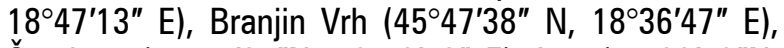
Čeminac $\left(45^{\circ} 41^{\prime} 24 " \mathrm{~N}, 18^{\circ} 40^{\prime} 12^{\prime \prime} \mathrm{E}\right)$, Lug $\left(45^{\circ} 39^{\prime} 48^{\prime \prime} \mathrm{N}\right.$, $\left.18^{\circ} 46^{\prime} 26^{\prime \prime} \mathrm{E}\right)$ and Vardarac $\left(45^{\circ} 37^{\prime} 25^{\prime \prime} \mathrm{N}, 18^{\circ} 46^{\prime} 13^{\prime \prime} \mathrm{E}\right)$. They were marked as CRO1, CRO2, CRO3, CRO4 and CR05, respectively. All locations in Croatia belong to the Baranja region. The samples collected in Serbia at locations Novi Kneževac $\left(46^{\circ} 3^{\prime} 0^{\prime \prime} \mathrm{N}, 20^{\circ} 6^{\prime} 0^{\prime \prime}\right.$ E), Futog

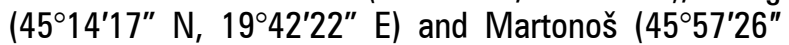
$\mathrm{N}, 1^{\circ} 55^{\prime} 00^{\prime \prime}$ E) were marked as SER1, SER2 and SER3, respectively. Novi Kneževac and Martonoš are situated in the North Banat District, Vojvodina province. Futog is situated in the southern part of Vojvodina in the middle of the Danube stream called Bačka. The samples collected in Hungary at locations Kalocsa $146^{\circ} 32^{\prime} 00^{\prime \prime}$ N 18 $59^{\prime} 08^{\prime \prime}$ E), Szeged (46 $16^{\prime} 10^{\prime \prime} N, 20^{\circ} 8^{\prime} 29^{\prime \prime}$ E) and Kistarcsa (47 $32^{\prime} 52^{\prime \prime} N, 19^{\circ} 15^{\prime} 48^{\prime \prime}$ E) were marked as HUN1, HUN2 and HUN3, respectively. Kalocsa is situated in Bács-Kiskun county, Szeged in Csongrád county and Kistarcsa in the Pest county of Hungary. Each sample was additionally marked with $\mathrm{S}$ (sweet) or $\mathrm{H}$ (hot). Accordingly, ten samples (5 sweet +5 hot) were col- lected in Croatia, 6 samples ( 3 sweet +3 hot) in Serbia and 6 samples ( 3 sweet +3 hot) in Hungary.

\section{Sample preparation}

Paprika samples were dehydrated in an oven and subjected to extraction procedures in methanol or acetonitrile. The extraction in methanol was performed by adding $1 \mathrm{~g}$ of dried paprika to $10 \mathrm{~mL}$ of $80 \%$ methanol (v/v). The extraction was carried out using an ultrasonic bath at $25^{\circ} \mathrm{C}$ for 30 minutes. Then the extracts were filtered through a nylon membrane filter of pore size $0.2 \mu \mathrm{m}$ (Whatman Inc.). The extracts were stored until analysis at $4^{\circ} \mathrm{C}$ in sealed glass test tubes. Methanolic extracts were used for the evaluation of total phenolics, total flavonoids and antioxidant activity (AOX).

The extraction in acetonitrile was used for the evaluation of capsaicinoids according to the method of Collins et al. (1995). After extraction, the samples were centrifuged and the supernatant was filtered through a membrane nylon filter of $0.2 \mu \mathrm{m}$ pore size (Whatmann Inc.). The extracts were kept in sealed glass vials at $4^{\circ} \mathrm{C}$ until analysis.

\section{Total phenolic content}

The total phenol content was determined by FolinCiocalteu's reagent (Singleton \& Rossi, 1965). The total phenolic content was expressed as $\mathrm{mg}$ of gallic acid equivalent (GAE) per $100 \mathrm{~g}$ of dry matter. All determinations were carried out in triplicate.

\section{Total flavonoid content}

The total flavonoid content was determined according to Molina-Quijada et al. (2010). The total flavonoid content was expressed as quercetin equivalents, i.e. $\mathrm{mg}$ of quercetin per $100 \mathrm{~g}$ of dry matter. All determinations were carried out in triplicate.

\section{Antioxidant activity}

The antioxidant scavenging ability of methanolic extracts against DPPH free radicals (DPPH ${ }^{*}$ ) was evaluated as described previously (Vinković Vrček et al., 2011). The results were expressed as $\mu$ mol TEAC per $100 \mathrm{~g}$ of dry matter. All determinations were conducted in triplicate.

\section{Total carotenoid content - red coloration of paprika}

The total carotenoid content in paprika extracts was determined according to FAO (2008). The total carotenoid content was expressed as \% of capsanthin and capsorubin using their extinction coefficient in acetone. Capsanthin and capsorubin are responsible for red coloration of paprika. All determinations were carried out in triplicate.

\section{Quantitative determination of capsaicinoids}

The content of capsaicinoids was measured on the HPLC Shimadzu Prominence system with the LC-20AD 
solvent delivery pump, SIL-20AC autosampler, CTO20AC column oven, RF-20A fluorescence detector and CBM-20A system controller. For data processing, software LabSolution was used. For the separation of capsaicin and dihydrocapsaicin, a Merck LiChrospher RP C18 125-4 column with $5 \mu \mathrm{m}$ particles of the stationary phase was used. Also, LiChrospher ${ }^{\circledR} 100 \mathrm{RP} 18(5 \mu \mathrm{m})$ LiChroCART ${ }^{\circledR}$ 4-4 guard column was used. Capsaicin and dihydrocapsaicin were determined according to the method of Collins et al. (1995). All measurements were made in duplicate and the concentration was determined from the calibration curve. Capsaicin contents were converted to Scoville Heat Units by multiplying the sum of capsaicin and dihydrocapsaicin concentrations (g capsaicin + dihydrocapsaicin per g of pepper dry weight) by the coefficient of the heat value for capsaicin $\left(1.6 \times 10^{7}\right)$.

\section{Statistical analysis}

Statistical analysis of data was conducted using factorial analysis of variance ANOVA by grouping the data depending on pungency. Normality of data was assessed by Shapiro-Wilks test $(p \leq 0.05)$. Fisher's LSD test was applied to judge statistical significance of differences between locations and cultivars/pungency using SAS 9.2 Statistical Package (2014). Mean values were considered significantly different when $p \leq 0.05$.

\section{RESULTS AND DISCUSSION}

\section{Phenolic compounds and total antioxidant activity}

Pepper is known to be an important source of antioxidative compounds like phenolics or flavonoids being mainly localized in the peel and depend on the type of cultivar and growing conditions (Marin et al. 2004). The phytochemical properties and antioxidant activities of the analysed paprika samples as final product of some pepper cultivars are shown in Table 1, 2, and Fig. 1. According to our results, the highest flavonoid content was observed in paprika from Szeged in Hungary (HUN2-H) and Futog in Serbia (SER2-H) in case of hot paprika. In sweet paprika samples, the highest flavonoid content was detected in the samples HUN2-S and SER1-S. Analysis of phenolics in sweet paprika revealed their highest content in sample CRO2-S (Fig. 1), whereas in hot paprika the highest content was detected in the sample SER2-H (Fig. 2). The lowest content of phenols was detected in sweet and hot paprika in the samples CRO3-S and SER3-H, respectively (Fig. 1 and 2). The total phenolic content ranged from 163.1 to $236.1 \mathrm{mg}$ of gallic acid per $100 \mathrm{~g}$ of sweet paprika (Fig. 1). In hot paprika samples, it ranged from 188.8 to $260.5 \mathrm{mg}$ of gallic acid per $100 \mathrm{~g}$ of paprika (Fig. 2). In a study by Škrovánková et al. (2017), hot paprika samples had higher content of phenolic compounds compared to sweet paprika which corresponds to results obtained in our study.

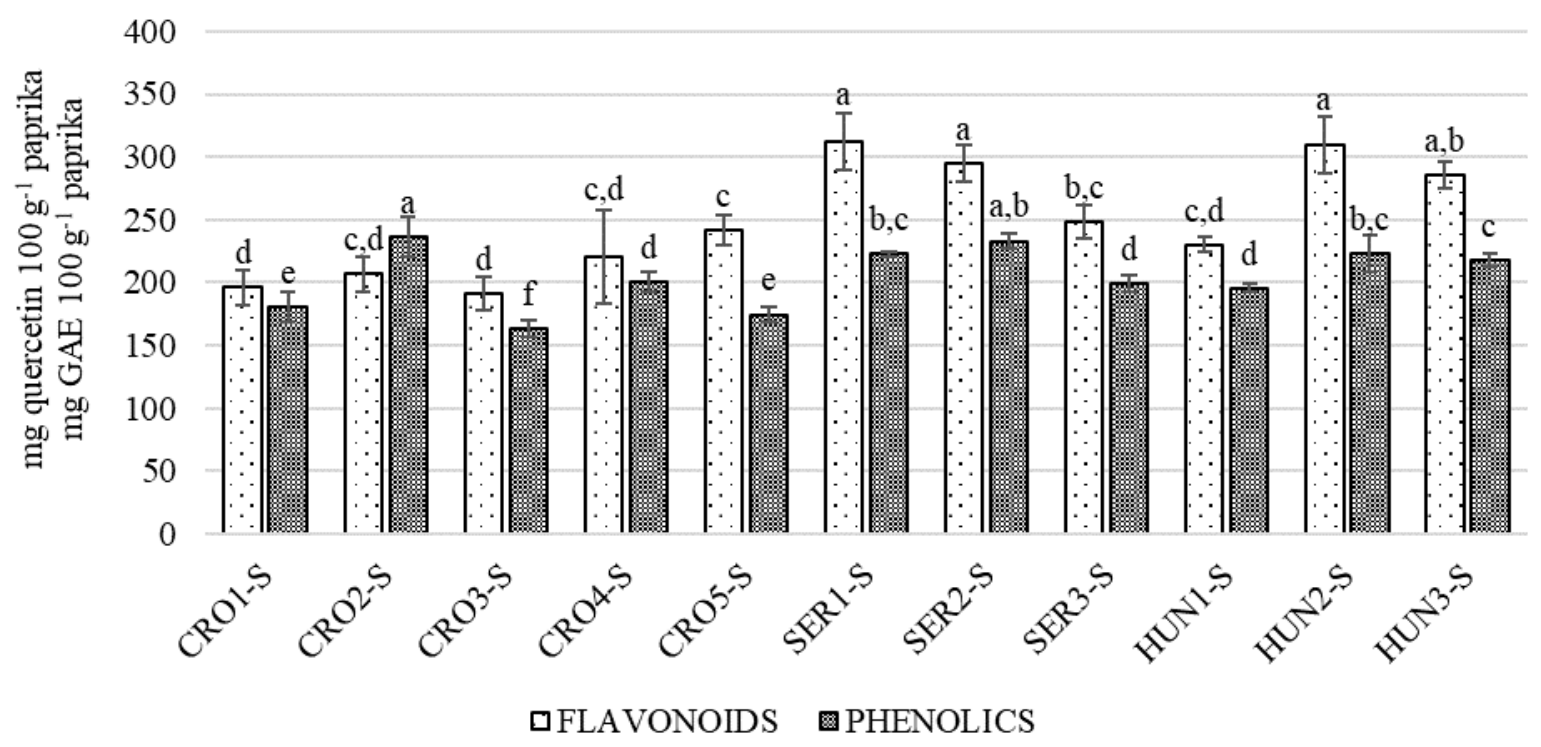

Figure 1. Average content of total flavonoids and phenolics in sweet paprika in the Eastern Danube Region during 2013/14. Values are expressed as mg quercetin $100 \mathrm{~g}^{-1}$ and $\mathrm{mg} \mathrm{GAE} 100 \mathrm{~g}^{-1}$ of ground paprika, respectively. Different letters denote significant differences $(\boldsymbol{p} \leq \mathbf{0 . 0 5})$ among samples

Grafikon 1. Prosječan sadržaj ukupnih flavonoida i fenola u slatkoj i ljutoj paprici Istočne dunavske regije tijekom 2013/14. Vrijednosti su izražene u mg ekvivalenta kvercetina $100 \mathrm{~g}^{-1}$ i mg GAE $100 \mathrm{~g}^{-1}$ mljevene začinske paprike. Vrijednosti obilježene različitim slovima se značajno razlikuju $(p \leq 0,05)$ 


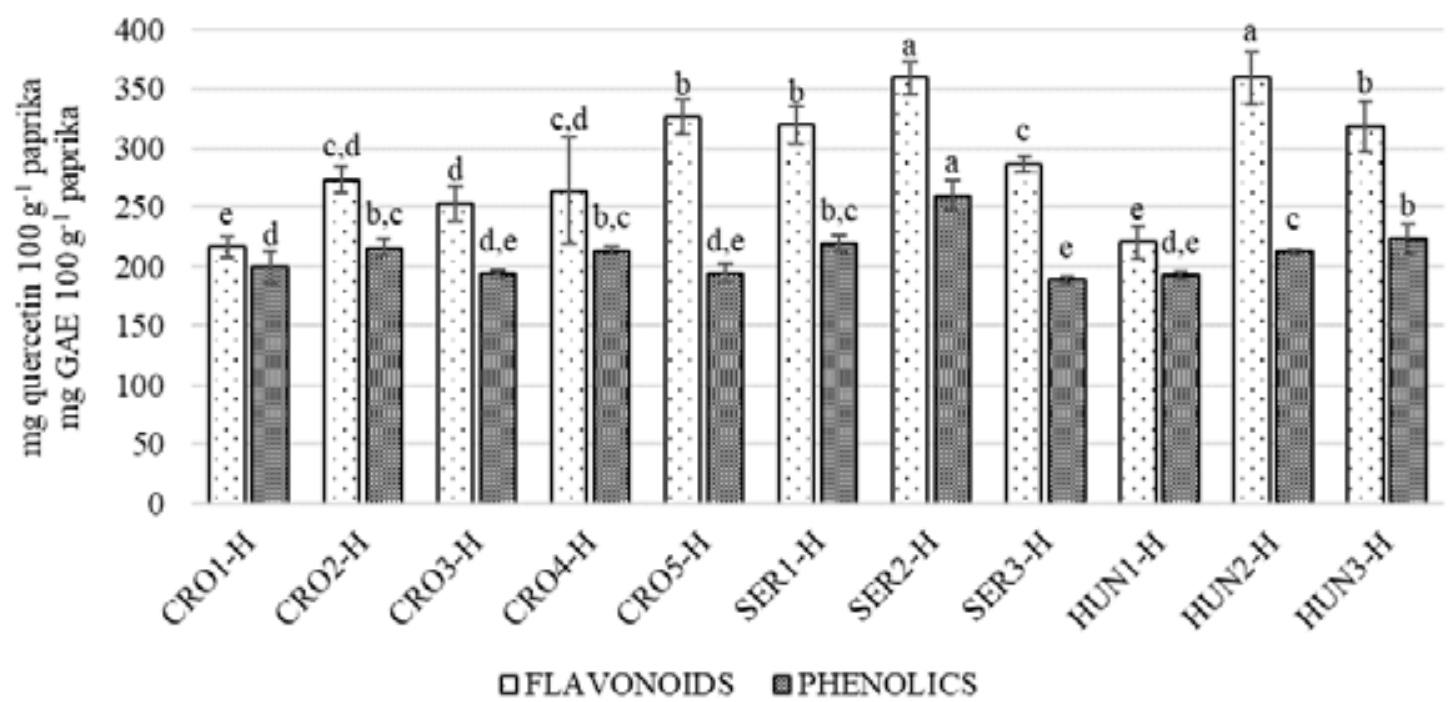

Figure 2. Average content of total flavonoids and phenolics in hot paprika in the Eastern Danube Region during 2013/14. Values are expressed as mg quercetin $100 \mathrm{~g}^{-1}$ and $\mathrm{mg} \mathrm{GAE} 100 \mathrm{~g}^{-1}$ of ground paprika, respectively. Different letters denote significant differences $(\boldsymbol{p} \leq 0.05)$ among samples

Grafikon 2. Prosječan sadržaj ukupnih flavonoida i fenola u slatkoj i ljutoj paprici Istočne dunavske regije tijekom 2013/14. Vrijednosti su izražene u mg ekvivalenta kvercetina $100 \mathrm{~g}^{-1} \mathrm{i} \mathrm{mg} \mathrm{GAE} 100 \mathrm{~g}^{-1}$ mljevene začinske paprike. Vrijednosti obilježene različitim slovima značajno se razlikuju $(p \leq 0.05)$

Comparing our results with results reported by Zimmer et al. (2012), the contents of phenolic compounds detected in both sweet and hot paprika samples were higher in our study. They have analysed phenolic content in Capsicum baccatum (149.3 to $187.5 \mathrm{mg}$ of GAE/g DW) while Reis et al. (2013) obtained similar results for dried fruits of Capsicum chinense (141.5 to $148.0 \mathrm{mg} \mathrm{GAE} / 100 \mathrm{~g}$ DW). Furthermore, the phenolic content in our study varied significantly among different paprika samples influenced by location where sampled. This variation can depend on plant maturity, geographic origin of peppers as well as the genotype $x$ maturity interaction (Russo \& Howard
2002; Deepa et al. 2007). Paprika obtained from Szeged in Hungary (HUN2-H) and Futog in Serbia (SER2-S) had the highest total antioxidant activity accompanied with highest content of total flavonoids (Table 1, Fig. 1 and 2). However, we could not find positive correlation between these parameters for other analysed samples. Also, we could not find positive correlation between total phenolic content and antioxidants activity, either similar observations were reported in recent studies emphasizing that phenolic compounds were not responsible for antioxidant activity (Scalzo et al., 2005; Deepa et al., 2007; Patthamakanokporn et al., 2008; Škrovánková et al., 2017).

Table 1. Average values of antioxidant activity (AOX) in sweet and hot paprika in the Eastern Danube Region during 2013/14. The means followed by different letters in the columns are significantly different $(p \leq 0.05)$. Asterisk indicate significant difference $(\boldsymbol{p} \leq 0.05)$ between sweet and hot paprika at the same location

Tablica 1. Prosječne vrijednosti antioksidativne aktivnosti (AOX) u slatkoj i ljutoj paprici Istočne dunavske regije tijekom 2013./14. Prosjeci označeni različitim slovima unutar istoga stupca značajno su različiti ( $p \geq 0.05)$. Zvjezdica označava značajnu razliku $(p \leq 0.05)$ između slatke i ljute paprike na istoj lokaciji

\begin{tabular}{|c|c|c|c|}
\hline $\begin{array}{l}\text { Sample } \\
\text { Uzorak }\end{array}$ & \multicolumn{2}{|c|}{$\begin{array}{l}\text { AOX ( } \mu \mathrm{M} \text { TEAC/100 g paprika) } \\
\text { AOX ( } \mu M \text { TEAC/100 g paprike) }\end{array}$} & \multirow[t]{2}{*}{$\begin{array}{l}\text { AOX - significant difference } \\
\text { AOX - značajna razlika }\end{array}$} \\
\hline $\begin{array}{l}\text { Pungency } \\
\text { Okus }\end{array}$ & $\begin{array}{l}\text { Sweet } \\
\text { Slatka }\end{array}$ & $\begin{array}{l}\text { Hot } \\
\text { Ljuta }\end{array}$ & \\
\hline CR01 & $11054.14 \pm 1014.54^{b}$ & $4160.02 \pm 195.49^{f, g}$ & * \\
\hline CR02 & $2413.35 \pm 439.08^{f}$ & $6448.46 \pm 1115.97^{d}$ & $*$ \\
\hline CR03 & $3221.13 \pm 597.07^{e, f}$ & $5661.62 \pm 103.79^{\mathrm{d}, \mathrm{e}}$ & $*$ \\
\hline CRO4 & $8007.08 \pm 210.25^{c}$ & $4705.89 \pm 302.70^{e, f}$ & * \\
\hline CR05 & $5161.29 \pm 363.77^{d}$ & $6200.16 \pm 300.49^{d}$ & $*$ \\
\hline SER1 & $3915.05 \pm 106.85^{\mathrm{e}}$ & $4264.69 \pm 511.78^{f, g}$ & n.s. \\
\hline SER2 & $12788.06 \pm 1448.02^{\mathrm{a}}$ & $9404.95 \pm 672.26^{c}$ & $*$ \\
\hline SER3 & $10224.51 \pm 844.78^{b}$ & $3506.71 \pm 324.32^{9}$ & $*$ \\
\hline HUN1 & $5778.90 \pm 808.25^{d}$ & $12857.18 \pm 748.75^{\mathrm{b}}$ & * \\
\hline HUN2 & $7992.06 \pm 825.11^{c}$ & $14332.16 \pm 1468.54^{a}$ & * \\
\hline HUN3 & $7783.84 \pm 439.53^{c}$ & $5666.95 \pm 904.88^{\mathrm{d}, \mathrm{e}}$ & * \\
\hline
\end{tabular}


In contrast, Medina-Juárez et al. (2012) found out the strongest correlation between the content of total flavonoids and antioxidant activity measured as a reduction of DPPH radical. Similar correlation was also found out for Moroccan paprika and it was suggested that total phenolic and carotenoid contents could serve as a useful indicator for the antioxidant activity of paprika (Zaki et al., 2013). However, this interpretation does not consider differences in the phenolic profiles: qualitatively (type of phenolics present) and quantitatively (the relative amounts or proportions of phenolics) present in different samples as well as synergistic, additive or antagonistic behaviour of phenolic compounds (JacoboVelázquez and Cisneros-Zevallos, 2009). Antioxidant activity significantly differed when comparing results of sweet and hot paprika samples at the same location (Table 1). This indicates strong relation between genotype and antioxidant activity, especially when taking into consideration high concentrations of capsaicinoids in hot paprika samples whose synthesis can depend on certain abiotic factors such as high temperature (Rahman et al., 2012) and thus they take part in plant response to abiotic stress. The antioxidant capacity of dried Capsicum spp. has been reported to be greatly dependent on capsaicinoids as well as carotenoids content. Nevertheless, it is also influenced by the drying process, implying a drastic reduction of the antioxidant activity (Caporaso et al., 2013).

\section{Carotenoids - capsanthin and capsorubin}

Moreover, the antioxidant activity of pepper fruits may be attributed also to carotenoids (Márkus et al., 1999; Russo and Howard, 2002; Deepa et al., 2007). We measured total carotenoids expressed as \% of capsanthin and capsorubin (Table 1) responsible for red coloration and determine the paprika quality. Averagely, the samples from Croatia (CR01, CRO4, CRO5) (Fig 3) had the highest level of carotenoids, while the lowest content was found out in the samples from Serbia (SER1, SER2) and Croatia (CRO3) (Fig. 3).

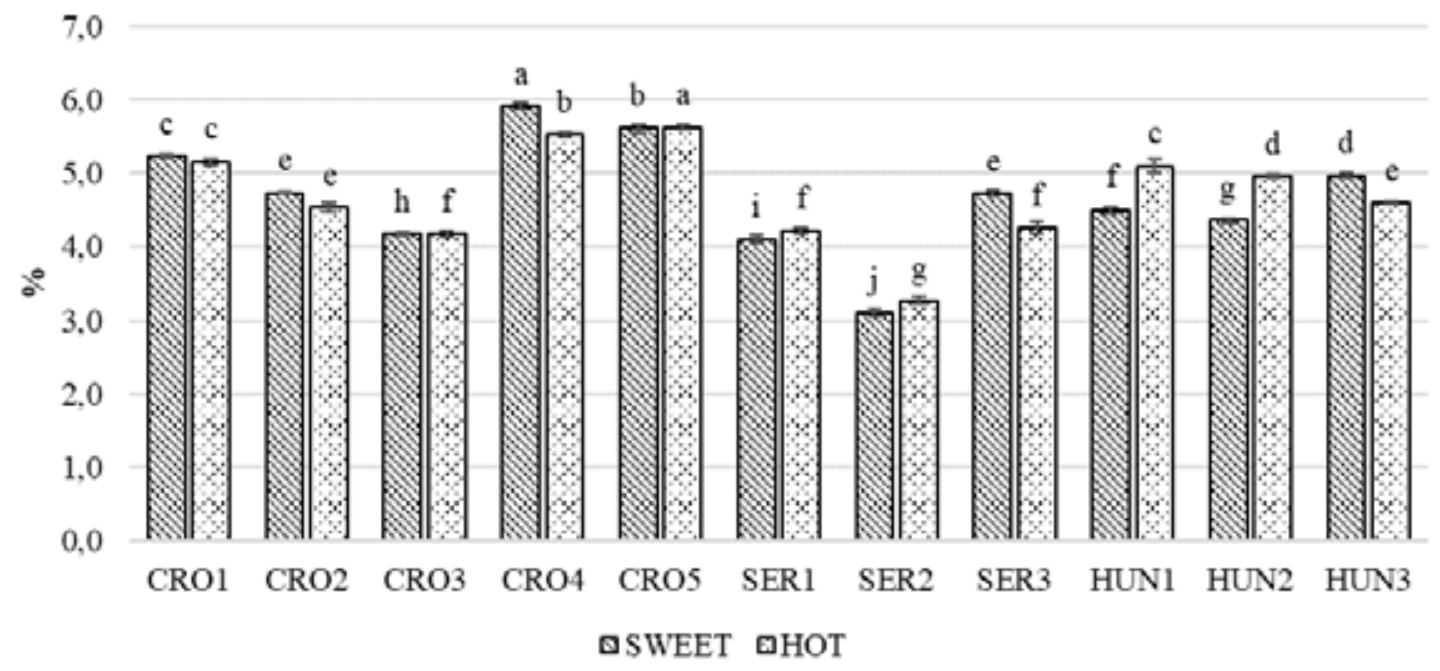

Figure 3. Average values of carotenoids content expressed as \% of capsanthin and capsorubin in sweet and hot paprika in the Eastern Danube Region during 2013/14. Different letters denote significant differences $(p \leq 0.05)$ among sweet or hot paprika samples

Grafikon 3. Prosječne vrijednosti karotenoida izražene kao postotak kapsantina i kapsorubina u slatkoj i ljutoj paprici

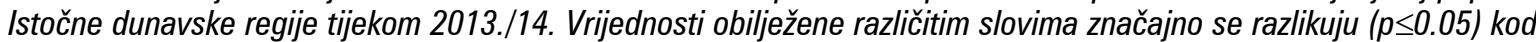
uzoraka slatke ili ljute paprike

Surprisingly, compared to other investigated parameters, carotenoids content varied at least regarding differences among sweet and hot paprika samples at the same location. However, carotenoids content differed significantly between locations for both sweet and hot paprika samples (Fig. 3). Carotenoid metabolism can be affected by environmental factors and their content tends to increase in plants as a response to stress such as drought and high temperatures (Munné-Bosch and Alegre, 2000; Belefant-Miller and Grunden, 2014). Carotenoids composition and content can vary due to the genetic characteristics of different pepper cultivars (Márkus et al., 1999; Russo and Howard, 2002). Also, the stability of main carotenoids has been found out to depend on drying conditions (Malchev et al., 1982). The storage conditions of ground paprika can affect the rate of color degradation depending on temperature and its duration (Carbonell et al., 1986; Addala et al., 2015), residual moisture content of the product (Lease and Lease, 1956), and increased surface area, particularly in the presence of unsaturated lipids (Kanner et al., 1976, 1977). The addition of seed to paprika can cause the carotenoid content decrease in except for unesterified violaxanthin, capsanthin, and cryptoxanthin as a result of dilution, but at the same time the addition of seeds can improve to a considerable extent the stability of carotenoid-type pigments in ground paprika during storage (Márkus et al., 1999). 


\section{Capsaicinoids and Scoville Heat Units (SHU)}

The sweet paprika samples analysed in the present study contained a significantly lower content of capsaicin (Fig. 4) compared to hot paprika samples, which was expected. However, we find this data interesting, as it was not expected to determine such concentration of capsaicinoids in sweet paprika samples.

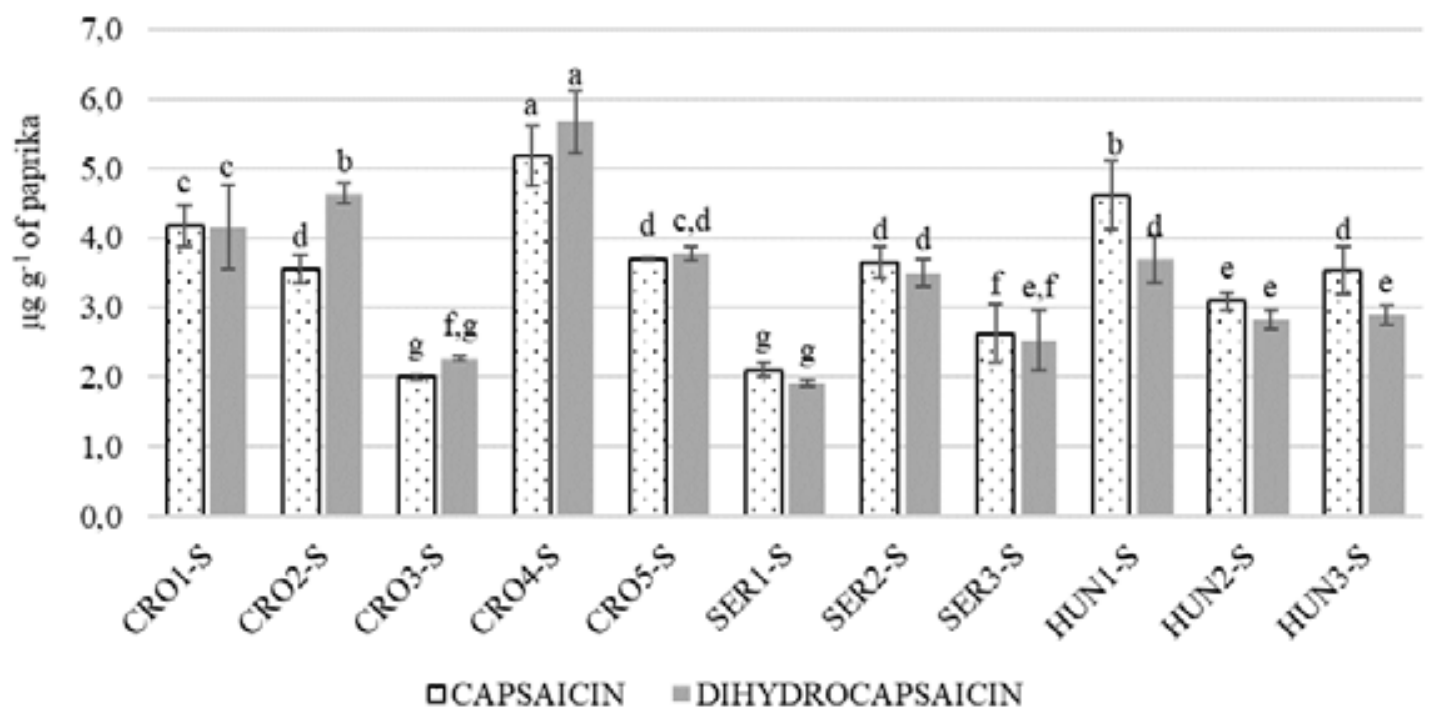

Figure 4. Average content of capsaicin and dihydrocapsaicin in sweet paprika samples. Values are expressed as $\boldsymbol{\mu} \mathbf{g ~}^{-1}$ of ground paprika. Different letters denote significant differences $(\boldsymbol{p} \leq \mathbf{0 . 0 5})$ among samples

Grafikon 4. Prosječan sadržaj kapsaicina i dihidrokapsaicina u svim uzorcima začinske paprike. Vrijednosti su izražene u $\mu g$ $g^{-1}$ mljevene paprike. Vrijednosti obilježene različitim slovima značajno se razlikuju ( $\left.p \leq 0.05\right)$

In general, the highest content of carotenoids and the pungency-defining alkaloids capsaicin and dihydrocapsaicin were determined in the hot paprika samples from Croatia ranging from $80 \mu \mathrm{g} \mathrm{g}^{-1}$ up to $210 \mu \mathrm{g} \mathrm{g}^{-1}$ of ground paprika (Fig. 5). These results confirm the hypothesis of Giuffrida et al. (2014) that carotenoids protect capsaicinoids from degradation. The highest content of capsaicin and dihydrocapsaicin found out in hot paprika samples at locations in Croatia (CR01-H $\mathrm{CRO5-H,} \mathrm{Fig.} \mathrm{5)} \mathrm{may} \mathrm{be} \mathrm{due} \mathrm{to} \mathrm{higher} \mathrm{temperature} \mathrm{dur-}$ ing fruit growth and development as capsaicin synthase activity might be increased in such conditions (Rahman et al., 2012), also referring to sweet paprika samples (Fig. 4).

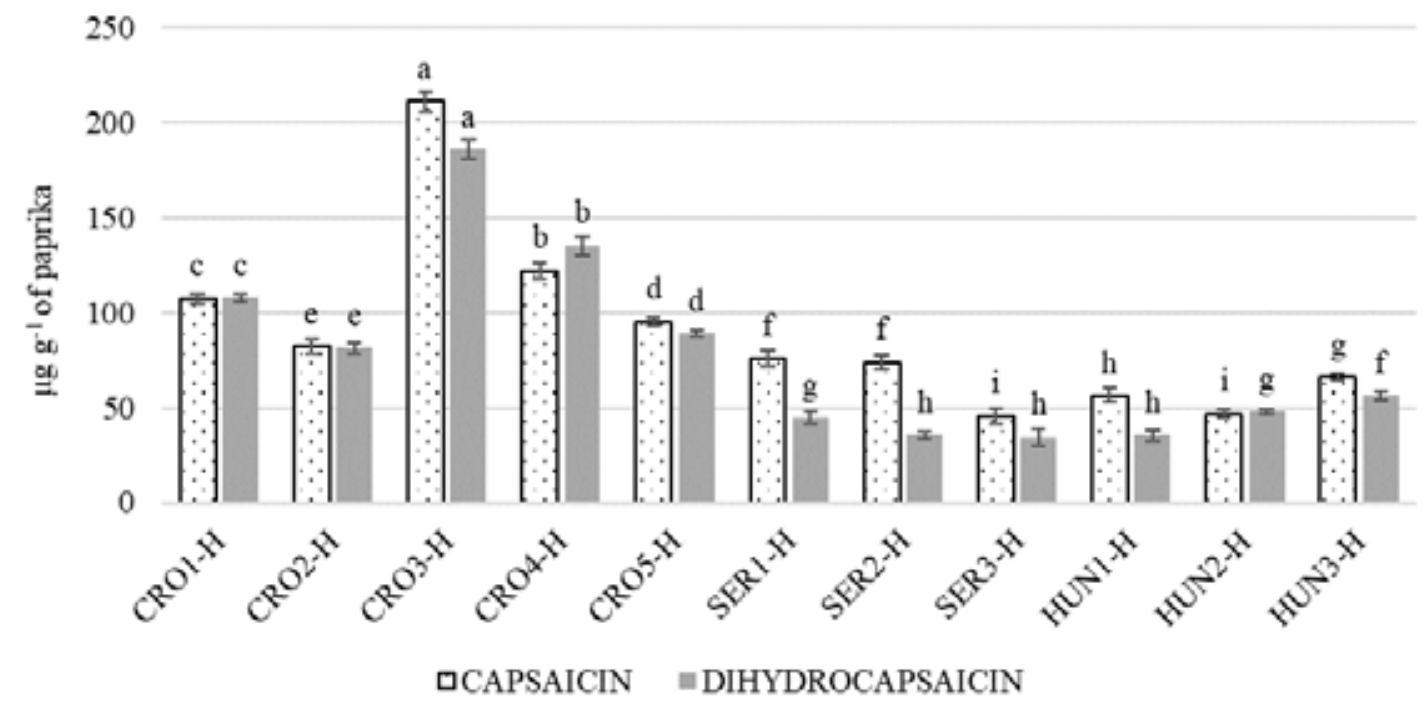

Figure 5. Average content of capsaicin and dihydrocapsaicin in the hot paprika samples. Values are expressed as $\boldsymbol{\mu} \mathbf{g ~}^{-1}$ of ground paprika. Different letters denote significant differences $(\boldsymbol{p} \leq \mathbf{0 . 0 5})$ among samples

Grafikon 5. Prosječan sadržaj kapsaicina i dihidrokapsaicina u uzorcima ljute začinske paprike. Vrijednosti su izražene u $\mu g$ $g^{-1}$ mljevene paprike. Vrijednosti obilježene različitim slovima značajno se razlikuju ( $\left.p \leq 0.05\right)$ 
Quantitative variation in the capsaicinoids content and Scoville heat units could also be explained by genotypic variation (Zewdie and Bosland, 2000; Ben-Chaim et al., 2006, Fig. 6) and differences in fruit maturation during harvest (Sukrasno and Yeoman, 1993; Buczkowska and Łabuda, 2015). Figure 6 shows difference in SHU between paprika (final product after drying and grinding) of Hungarian wax hot pepper cv. Kalocsai V2 from this study and other cultivars of hot peppers as data about this cultivar pungency are very limited. Accordingly, cv. Kalocsai V2 together with other
Hungarian wax hot pepper cultivars belongs to mild pungent group. The content of particular capsaicinoids in hot pepper fruits depends on the fruit parts used for making ground paprika because biosynthesis of capsaicinoids takes place in the fruits, placenta and epidermal cells. From here, they are distributed to the seeds and pericarp, and in small quantities to the vegetative parts of plants (Contreras-Padilla and Yahia, 1998; Estrada et al., 2002; Pandhair and Sharma, 2008; Ben MansourGueddes et al., 2012). Accordingly, pungency strongly depends on the dry fruit processing methods.

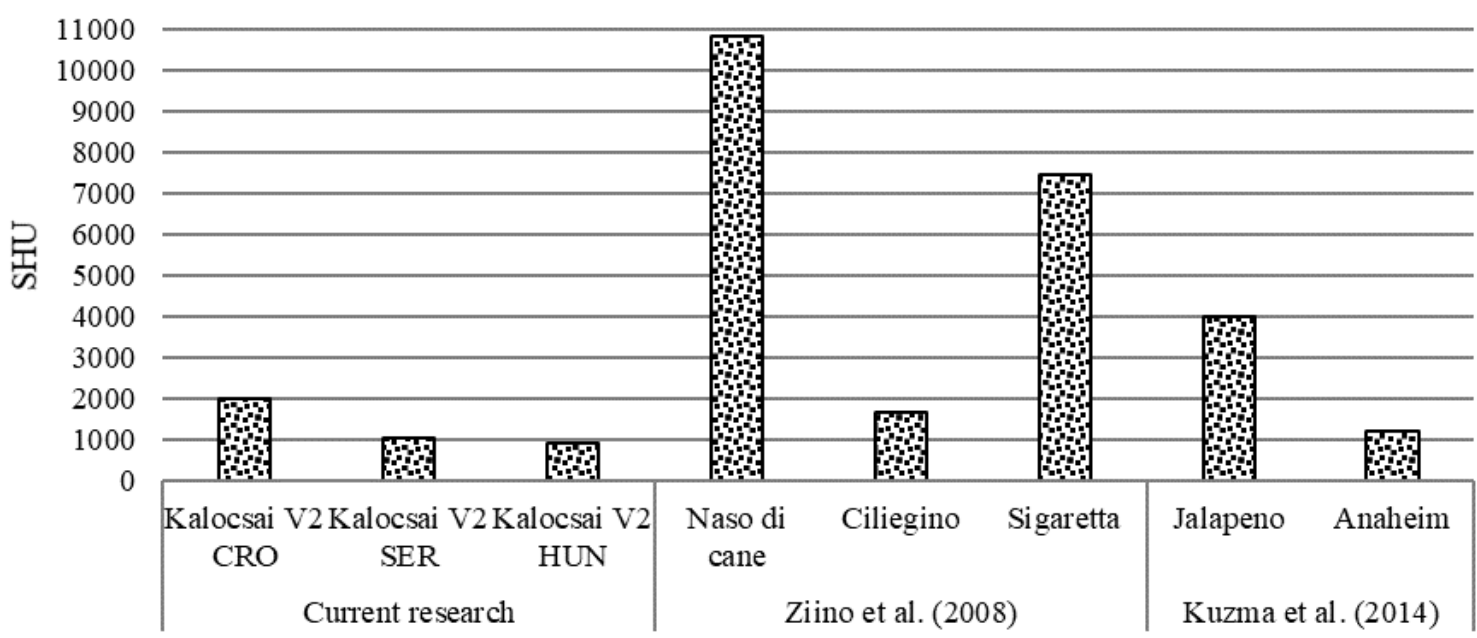

Figure 6. Average Scoville Heat Unit (SHU) of different hot pepper varieties

Grafikon 6. Prosječne vrijednosti Scovilleovih jedinica ljutine (SHU) različitih ljutih sorata paprike

\section{CONCLUSION}

The data on phytochemical composition of sweet and hot paprika obtained from Hungarian wax pepper are very limited. The results from our study pointed out the differences in the chemical composition of paprika obtained from two different pepper cultivars produced in three different states of the Eastern Danube region. The composition and level of metabolites as well as antioxidant activity in paprika samples varied greatly depending on location where produced. In general, paprika from Croatia had the highest carotenoid content but the lowest phenols and flavonoids content. The hot paprika samples from Croatia had the highest content of capsaicin and dihydrocapsaicin. The results of this investigation indicate that bioactive compounds in paprika can vary greatly depending on their geographical origin. However, this variation can also be due to different production technology and processing methods. Further studies are needed to reveal the specific factors responsible for variation of bioactive compounds content in paprika during production and processing.

\section{ACKNOWLEDGEMENT}

This study was an integral part of project entitled "Analysis and standardization of Baranyan paprika" financed by Josip Juraj Strossmayer University of Osijek.

\section{REFERENCES}

1. Addala, R., Vasavada, M., Dong, J., \& Subramanian, S. (2015). Effect of storage conditions on rate of color degradation of paprika based products. Journal of Food Processing \& Technology, 6(3), 1-6. https://doi. org/10.4172/2157-7110.1000423

2. Belefant-Miller, H., \& Grunden, E. (2014). Carotenoid metabolism is induced in rice bran during very high temperature stress. Journal of the Science of Food and Agriculture, 94(9), 1808-1815. https://doi.org/10.1002/ jsfa.6496

3. Ben-Chaim, A., Borovsky, Y., Falise, M., Mazourek, M., Kang, B. C., Paran, I., \& Jahn, M. (2006). OTL analysis for capsaicinoid content in Capsicum. Theoretical and Applied Genetics, 113(8), 1481-1490. https://doi. org/10.1007/s00122-006-0395-y

4. Ben Mansour-Gueddes, S., Tarchoun, N., Ibn MaaouiaHouimli, S., \& Saguem, S. (2012). Capsaicinoids content in four Tunisian pepper varieties grown in an open field (Capsicum annuum L.). Continental Journal of Agronomy, 6(1), 8-13. https://doi.org/10.5707/cja.2012.6.1.8.13

5. Buczkowska, H., \& Łabuda, H. (2015). Utility and biological value of hot pepper fruits from a single harvest. Acta Scientiarum Polonorum Hortorum Cultus, 14(2), 133-143. http://hortorumcultus.actapol.net/pub/14_2_133.pdf

6. Caporaso, N., Paduano, A., Nicoletti, G., \& Sacchi, R. (2013). Capsaicinoids, antioxidant activity, and volatile 
compounds in olive oil flavored with dried chili pepper (Capsicum annuum). European Journal of Lipid Science and Technology, 115(12), 1434-1442. https:// doi.org/10.1002/ejtt.201300158

7. Carbonell, J. V., Pinaga, F., Yusá, V., \& Pena, J. L. (1986). The dehydration of paprika with ambient and heated air and the kinetics of color degradation during storage. Journal of Food Engineering, 5(3), 179-193. https://doi. org/10.1016/0260-8774(86)90024-5

8. Cisneros-Pineda, 0., Torres-Tapia, L. W., GutiérrezPacheco, L. C., Contreras-Martín, F., González-Estrada, T., \& Peraza-Sánchez, S. R. (2007). Capsaicinoids quantification in chili peppers cultivated in the state of Yucatan, Mexico. Food Chemistry, 104(4), 1755-1760. https://doi.org/10.1016/j.foodchem.2006.10.076

9. Collins, M. D., Wasmund, L. M., \& Bosland, P. W. (1995). Improved method for quantifying capsaicinoids in Capsicum using high-performance liquid chromatography. HortScience, 30(1), 137-139. http://hortsci. ashspublications.org/content/30/1/137.full.pdf+html

10. Contreras-Padilla, M., \& Yahia, E. M. (1998). Changes in capsaicinoids during development, maturity, and senescence of chile peppers and relation with peroxidase activity. Journal of Agricultural and Food Chemistry, 46(6), 2075-2079. https://doi.org/10.1021/jf970972z

11. Deepa, N., Kaur, C., George, B., Singh, B., \& Kapoor, H. C. (2007). Antioxidant constituents in some sweet pepper (Capsicum annuum L.) genotypes during maturity. LWT - Food Science and Technology, 40(1), 121-129. https:// doi.org/10.1016/j.lwt.2005.09.016

12. Djamgoz, M. B. A., \& Isbilen, B. (2006). Dietary compounds as anti-cancer agents: A preliminary evaluation of ion channels and membrane excitability as possible target mechanisms. Turkish Journal of Biochemistry, 31(2), 57-68.

13. Estrada, B., Bernal, M., Díaz, J., Pomar, F., \& Merino, F. (2000). Fruit development in Capsicum annuum: changes in capsaicin, lignin, free phenolics, and peroxidase patterns. Journal of Agricultural and Food Chemistry, 48(12), 6234-6239. https://doi.org/10.1021/jf000190x

14. Estrada, B., Bernal, M. A., Diaz, J., Pomar, F., \& Merino, F. (2002). Capsaicinoids in vegetative organs of Capsicum annuum L. in relation to fruiting. Journal of Agricultural and Food Chemistry, 50(5), 1188-1191. https://doi.org/10.1021/jf011270j

15. FAO (2008). Paprika extract. Compendium of food additive specifications. Joint FAO/WHO Expert Committee on Food Additives. Roma, Italy.

16. Fox, A. J., Del Pozo-Insfran, D., Hee Lee, J., Sargent, S. A., \& Talcott, S. T. (2005). Ripening-induced chemical and antioxidant changes in bell peppers as affected by harvest maturity and postharvest ethylene exposure. HortScience, 40(3), 732-736. http://hortsci.ashspublications.org/content/40/3/732.full.pdf +html

17. Giuffrida, D., Dugo, P., Torre, G., Bignardid, C., Cavazzad, A., Corradinid, C., \& Dugoa, G. (2013). Characterization of 12 Capsicum varieties by evaluation of their carotenoid profile and pungency determination. Food Chemistry, 140(4), 794-802. https://doi.org/10.1016/j. foodchem.2012.09.060
18. Giuffrida, D., Dugo, P., Torre, G., Bignardid, C., Cavazzad, A., Corradinid, C., \& Dugoa, G. (2014). Evaluation of carotenoids and capsaicinoids content in powder of red chilli peppers during one year of storage. Food Research International, 65(B), 163-170. https://doi.org/10.1016/j. foodres.2014.06.019

19. Govindarajan, V. S. (1986). Capsicum - production, technology, chemistry, and quality. Part III. Chemistry of the color, aroma and pungency stimuli. Critical Reviews in Food Science and Nutrition, 24(3), 245-255. https:// doi.org/10.1080/10408398609527437

20. Govindarajan, V. S., \& Sathyanarayana, M. N. (1991). Capsicum-production, technology, chemistry, and quality. Part V. Impact on physiology, pharmacology, nutrition, and metabolism; structure, pungency, pain, and desensitization sequences. Critical Reviews in Food Science and Nutrition, 29(6), 435-474. https://doi. org/10.1080/10408399109527536

21. Jacobo-Velázquez, D. A., \& Cisneros-Zevallos, L. (2009) Correlations of antioxidant activity against phenolic content revisited: a new approach in data analysis for food and medicinal plants. Journal of Food Science, 74(9), R107-113. https://doi.org/10.1111/j.17503841.2009.01352.x

22. Kalt, W. (2005). Effects of production and processing factors on major fruit and vegetable antioxidants. Journal of Food Science, 70(1), 11-19. https://doi. org/10.1111/j.1365-2621.2005.tb09053.x

23. Kanner, J., Mende, H., \& Budowski, P. (1976). Carotene oxidizing factors in red pepper fruits (Capsicum annuum L.): ascorbic acid. Journal of Food Science, 41(1), 183-185. https://doi.org/10.1111/j.1365-2621.1976. tb01131.x

24. Kanner, J., Mende, H., \& Budowski, P. (1977). Carotene oxidizing factors in red pepper fruits (Capsicum annuum L.): peroxidase activity. Journal of Food Science, 42(6), 1549-1551. https://doi.org/10.1111/j.1365-2621.1977. tb08422.x

25. Lease, J. G., \& Lease, E. J. (1956). Factors affecting the retention of red color in peppers. Food Technology, 10(8), 368-373.

26. Lu, J., Papp, L. V., Fang, J., Rodriguez-Nieto, S., Zhivotovsky, B., \& Holmgren, A. (2006). Inhibition of mammalian thioredoxin reductase by some flavonoids: Implications for myricetin and quercetin anticancer activity. Cancer Research, 66(8), 4410-4418. https://doi. org/10.1158/0008-5472.CAN-05-3310

27. Malchev, E., Loncheva, N., Tanchev, S., \& Kalpakchieva, K. (1982). Quantitative changes in carotenoids during the storage of dried red pepper. Nahrung, 26(5), 415420. https://doi.org/10.1002/food.19820260503

28. Maoka, T., Mochida, K., Kuzoka, M., Ito, Y., Fujiwara, Y., Hashimoto, K., ... \& Nishino, H. (2001). Cancer chemopreventive activity of carotenoids in the fruits of red paprika Capsicum annuum L. Cancer Letters, 172(2), 103-109. https://doi.org/10.1016/S03043835(01)00635-8

29. Marin, A., Ferreres, F., Tomas-Barberan, F. A., \& Gil, M. I. (2004). Characterization and quantification of antioxidant constituents of sweet pepper (Capsicum annuum 
L.). Journal of Agricultural and Food Chemistry, 52(12), 3861-3869. https://doi.org/10.1021/jf0497915

30. Márkus, F., Daood, H. G., Kapitány, J., \& Biacs, P. A. (1999). Change in the carotenoid and antioxidant content of spice red pepper (paprika) as a function of ripening and some technological factors. Journal of Agricultural and Food Chemistry, 47(1), 100-107. https:// doi.org/10.1021/jf980485z

31. Medina-Juárez, L. A., Molina-Quijada, D. M. A., Del ToroSánchez, C. L., González-Aguilar, G. A., \& Gámez-Meza, N. (2012). Antioxidant activity of peppers (Capsicum annuum L.) extracts and characterization of their phenolic constituents. Interciencia, 37(8), 588-593.

32. Molina-Quijada, D. M. A., Medina-Juarez, L. A., GonzalezAguilar, G. A., Robles-Sanchez, R. M., \& Gamez-Meza, N. (2010). Compuestos fenólicos y actividad antioxidante de cáscara de uva (Vitis vinifera L.) de mesa cultivada en el noroeste de México. CyTA - Journal of Food, 8(1), 57-63. https://doi.org/10.1080/19476330903146021

33. Munné-Bosch, S., \& Alegre, L. (2000). Changes in carotenoids, tocopherols and diterpenes during drought and recovery, and the biological significance of chlorophyll loss in Rosmarinus officinalis plants. Planta, 210(6), 925-31. https://doi.org/10.1007/s004250050699

34. Pandhair, V., \& Sharma, S. (2008). Acumulation of capsaicin in seed, pericarp and placenta of Capsicum annuum L. fruit. Journal of Plant Biochemistry and Biotechnology, 17(1), 23-27. https://doi.org/10.1007/BF03263255

35. Patthamakanokporn, 0., Puwastien, P., Nitithamyong, A., \& Sirichakwal, P. P. (2008). Changes of antioxidant activity and total phenolic compounds during storage of selected fruits. Journal of Food Composition and Analysis, 21(3), 241-248. https://doi.org/10.1016/j. jfca.2007.10.002

36. Phimchan, P., \& Techawongstien, S. (2012). Impact of drought stress on the accumulation of capsaicinoids in Capsicum cultivars with different initial capsaicinoid levels. HortScience, 47(9), 1204-1209. http://hortsci. ashspublications.org/content/47/9/1204.full.pdf

37. Rahman, M. J., Inden, H., \& Hossain, M. M. (2012). Capsaicin content in sweet pepper (Capsicum annuum L.) under temperature stress. Acta Horticulturae, 936, 195201. https://doi.org/10.17660/ActaHortic.2012.936.23

38. Rahman, M. J., \& Inden, H. (2012). Antioxidant content and quality of fruits as affected by nigari, an effluent of salt industries, and fruit ages of sweet pepper (Capsicum annuum L.). Journal of Agricultural Science, 4(10), 105114. http://dx.doi.org/10.5539/jas.v4n10p105

39. Reis, R. C., Castro, V. C., Devilla, I. A., Oliveira, C. A., Barbosa, L. S., \& Rodovalho, R. (2013). Effect of drying temperature on the nutritional and antioxidant qualities of Cumari peppers form Pará. Brazilian Journal of Chemical Engineering, 30(2), 337-343. http://dx.doi. org/10.1590/S0104-66322013000200011
40. Russo, V. M., \& Howard, L. R. (2002). Carotenoids in pungent and nonpungent peppers at various developmental stages grown in the field and glass house. Journal of the Science of Food and Agriculture, 82(6), 614-615. https://doi.org/10.1002/jsfa.1099

41. SAS Statistical Package, 9.2. (2014.): Cary (NC): SAS Institute.

42. Scalzo, J., Politi, A., Pellegrini, N., Mezzetti, B., \& Battino, M. (2005). Plant genotype affects total antioxidant capacity and phenolic contents in fruit. Nutrition, 21(2), 207-213. https://doi.org/10.1016/j.nut.2004.03.025

43. Singleton, V. L., \& Rossi, J. A. (1965). Colorimetry of Total Phenolics with Phosphomolybdic-Phosphotungstic Acid Reagents. American Journal of Enology and Viticulture, 16(3), 144-158.

44. Sukrasno, N., \& Yeoman, M. M. (1993). Phenylpropanoid metabolism during growth and development of Capsicum frutescens fruits. Phytochemistry, 32(4), 839844. https://doi.org/10.1016/0031-9422(93)85217-F

45. Škrovánková, S., Mlček, J., Orsavová, J., Juríková, T., \& Drímalová, P. (2017). Polyphenols content and antioxidant activity of paprika and pepper spices. Potravinarstvo Slovak Journal of Food Sciences, 11(1), 52-57. https://dx.doi.org/10.5219/695

46. Tonin, F. G., Jager, A. V., Micke, G. A., Farah, J. P. S., \& Tavares, M. F. M. (2005). Optimization of the separation of flavonoids using solvent-modified micellar electrokinetic chromatography. Electrophoresis, 26(17), 33873396. https://doi.org/10.1002/elps.200500362

47. Vinković Vrček, I., Bojić, M., Žuntar, I., Mendaš, G., \& Medić-Šarić, M. (2011). Phenol content, antioxidant activity and metal composition of Croatian wines deriving from organically and conventionally grown grapes. Food Chemistry, 124(1), 354-361. https://doi. org/10.1016/j.foodchem.2010.05.118

48. Zaki, N., Hakmaoui, A., Ouatmane, A., Hasib, A., \& Fernandez-Trujilo, J. P. (2013). Bioactive components and antioxidant activity of Moroccan paprika (Capsicum annum L.) at different period harvesting and processing. Journal of Biology, Agriculture and Healthcare, 3(8), 1-8.

49. Zewdie, Y. \& Bosland, P. W. (2000). Evaluation of genotype, environment, and genotype-by-environment interaction for capsaicinoids in Capsicum annuum L. Euphytica, 111(3), 185-190. https://doi. org/10.1023/A:1003837314929

50. Zimmer, A. R., Leonardi, B., Miron, D., Schapoval, E., Rodrigues de Oliveira, J., \& Gosmann, G. (2012). Antioxidant and anti-inflammatory properties of Capsicum baccatum: From traditional use to scientific approach. Journal of Ethnopharmacology, 139(1), 228233. https://doi.org/10.1016/j.jep.2011.11.005 


\section{FITOKEMIJSKI SASTAV MLJEVENE ZAČINSKE PAPRIKE IZ ISTOČNE DUNAVSKE REGIJE}

\section{SAŽETAK}

Cilj ovog istraživanja bio je utvrditi fitokemijski sastav slatke i ljute začinske paprike podrijetlom iz različitih uzgojnih područja u Istočnoj dunavskoj regiji, tj. u Hrvatskoj, Srbiji i Mađarskoj. Dobiveni rezultati pokazali su kako se sastav i razina metabolita, kao i antioksidacijska aktivnost, u uzorcima začinske paprike značajno razlikuju između različitih uzgojnih područja. Prvi su put istaknute jasne razlike u kemijskome sastavu slatkih i ljutih sorata mađarske paprike proizvedene u tri različite države Istočne dunavske regije. Općenito, uzorci paprike iz Hrvatske imali su najveći sadržaj karotenoida, ali najniže vrijednosti fenola i flavonoida. Uzorci ljute paprike iz Hrvatske imali su najveći sadržaj kapsaicina i dihidrokapsaicina, kao i najviše Scovilleovih jedinica ljutine. Stoga, ovo istraživanje ukazuje na prikladnost određenih uzgojnih područja za dobivanje paprike željenoga kemijskoga sastava. Podatci su vrlo zanimljivi i važni za prehrambeno prerađivačku i farmaceutsku industriju, kao i za usmjeravanje regionalnih proizvođača prema dobivanju kvalitetne mljevene paprike.

Ključne riječi: paprika, kapsaicinoidi, fenoli, karotenoidi, antioksidativna aktivnost, Istočna dunavska regija

(Received on 9 July 2018; accepted on 16 November 2018 - Primljeno 09. srpnja 2018.; prihvaćeno 16. studenoga 2018.) 